\title{
Antimicrobial Activity of Extracts of Turmeric (Curcuma longa) and Garlic (Aliium sativum) Against Selected Bacterial Clinical Isolates
}

\author{
Zerdeçal (Curcuma longa) ve Sarımsak (Allium sativum) Özlerinin Seçilmiş Bakteriyel Klinik \\ Izolatlara Karşı Antimikrobiyal Aktivitesi
}

\author{
(1) Nafiu Muhammad WADA ${ }^{1}$, (1) Ahmad Adamu AMBI ${ }^{1}$, (1) Ahmad Aliyu IBRAHIM ${ }^{2}$, (1) Saadatu Kirfi BELLO ${ }^{1}$, (1) Abdullahi UMAR ${ }^{1}$, \\ (1D) Dalukus Timothy JAMES ${ }^{1}$
}

${ }^{1}$ Federal Polytechnic Bauchi, Department of Science Laboratory Technology, Bauchi, Nigeria

2Federal Polytechnic Bauchi, Department of Forestry Technology, Bauchi, Nigeria

\section{Abstract}

Introduction: Pathogens have persisted as major agents in the progress of infections that constitute a threat to human health the world over. Extracting remedies from plants is a longstanding human tradition. This study assesses the antimicrobial action of extracts of turmeric (Curcuma longa) and garlic (Allium sativum) against several bacterial clinical isolates.

Materials and Methods: The phytochemical constituents of ethanolic and aqueous extracts of turmeric and garlic and their susceptibility in single and combined absorptions were determined using a Clinical and Laboratory Standards Institute standard.

Results: Steroids, flavonoids, terpenoids, and alkaloids were detected in both extracts, whereas anthraquinone was only present in turmeric. On the other hand, tannins and saponins were present in extracts of garlic. Ethanolic extract of garlic showed a zone of inhibition measuring $12 \mathrm{~mm}$ at the absorption of $100 \mathrm{mg} / \mathrm{ml}$ against Staphylococcus aureus, a zone of inhibition $10 \mathrm{~mm}$ at a concentration of $100 \mathrm{mg} / \mathrm{ml}$ against Escherichia coli and a zone of inhibition of $7 \mathrm{~mm}$ at a concentration of $100 \mathrm{mg} / \mathrm{ml}$ against Klebsiella pneumoniae. The aqueous extract of the same garlic was effective against the tested bacteria. Ethanolic extract of turmeric showed the largest zone of inhibition of $13 \mathrm{~mm}$ at a concentration of $100 \mathrm{mg} / \mathrm{ml}$ against Staphylococcus aureus and $7 \mathrm{~mm}$ at a concentration of $100 \mathrm{mg} / \mathrm{ml}$ against Klebsiella pneumoniae. Equally, the aqueous extract of turmeric showed the highest zone of inhibition of $11 \mathrm{~mm}$ at a concentration of $100 \mathrm{mg} / \mathrm{ml}$ on Staphylococcus aureus and $7 \mathrm{~mm}$ against Klebsiella pneumoniae. The aqueous extract of garlic was active against the isolate, and the combination of the two extracts was active against the tested organism.

Conclusion: Spices can be used as effective antimicrobial agents against both Gram-positive and Gram-negative bacteria in both individual and combined forms.

Keywords: Turmeric, garlic, Escherichia coli, Klebsiella pneumoniae, Staphylococcus aureus

\section{Öz}

Giriş: Patojenler, dünya genelinde insan sağlığına tehdit oluşturan enfeksiyonların etkenleri olarak varlığını sürdürmüştür. Bitkilerden çare bulmak uzun süredir devam eden bir insan geleneğidir. Bu çalışma, zerdeçal (Curcuma longa) ve sarımsak (Allium sativum) özlerinin çeşitli bakteriyel klinik izolatlara karşı antimikrobiyal etkisini değerlendirmektedir.

Gereç ve Yöntemler: Zerdeçal ve sarımsağın etanolik ve sulu özlerinin fitokimyasal bileşenleri ve bunların tek ve birleşik absorpsiyonlardaki duyarlılıkları, bir Klinik ve Laboratuvar Standartları Enstitüsü standardı kullanılarak belirlendi.

Cite this article as: Wada NM, Ambi AA, Ibrahim AA, Bello SK, Umar A, James DT. Antimicrobial Activity of Extracts of Turmeric (Curcuma longa) and Garlic (Aliium sativum) Against Selected Bacterial Clinical Isolates. Mediterr J Infect Microb Antimicrob. 2021;10:6. 
Bulgular: Steroidler, flavonoidler, terpenoidler ve alkaloidler her iki özde de tespit edilirken, antrakinon sadece zerdeçalda mevcuttu. Öte yandan sarımsak özlerinde tanenler ve saponinler de mevcuttu. Sarımsağın etanolik özü, Staphylococcus aureus'a karşı 100 mg/ml absorpsiyonda 12 mm'lik bir inhibisyon bölgesi, Escherichia coli'ye karşı $100 \mathrm{mg} / \mathrm{ml}$ 'lik bir konsantrasyonda 10 mm'lik bir inhibisyon bölgesi ve Klebsiella pneumoniae'ye karşı 100 mg/ml'lik bir konsantrasyonda 7 mm'lik bir inhibisyon bölgesi gösterdi. Aynı sarımsağın sulu özü, test edilen bakterilere karşı etkiliydi. Zerdeçalın etanolik özü, Staphylococcus aureus'a karşı $100 \mathrm{mg} / \mathrm{ml}$ 'lik bir konsantrasyonda 13 mm'lik ve Klebsiella pneumoniae'ye karşı $100 \mathrm{mg} / \mathrm{ml}$ 'lik bir konsantrasyonda 7 mm'lik en büyük inhibisyon bölgesini gösterdi. Aynı şekilde, sulu zerdeçal özü, Staphylococcus aureus'a karşı 100 mg/ml'lik bir konsantrasyonda 11 mm'lik ve Klebsiella pneumoniae'ye karşı 100 mg/ml'lik bir konsantrasyonda 7 mm'lik en büyük inhibisyon bölgesini gösterdi. Sulu sarımsak özü izolata karşı aktifti ve iki özün kombinasyonu test edilen organizmaya karşı aktifti.

Sonuç: Baharatlar, hem bireysel hem de kombine formlarda hem Gram-olumlu hem de Gram-olumsuz bakterilere karşı etkili antimikrobiyal ajanlar olarak kullanılabilir.

Anahtar Kelimeler: Zerdeçal, sarımsak, Escherichia coli, Klebsiella pneumoniae, Staphylococcus aureus

\section{Introduction}

The medicinal importance of plants consists of some chemical substances that affect their physiological action on the human body. Plants play a specific role in traditional medicine, as they contain phytochemical compounds including steroids, alkaloids, terpenoids, flavonoids, phenolics, and carotenoids ${ }^{[1]}$. Herbs and spices have been shown to decrease inflammation, protect against bacteria, help detoxify the liver, cleanse the lungs and perhaps other organs, and protect against cell loss that may contribute to rheumatoid arthritis, osteoporosis, heart disease, as well as other degenerative diseases ${ }^{[2]}$. These plants are also beneficial as prophylactic agents against various pathogenic infections due to their various phytochemicals and active compounds ${ }^{[1]}$.

In addition to their effects on the taste and scent of food, spices are been used for their antimicrobial properties ${ }^{[3]}$. Some of the natural compounds found in different spices serve as antimicrobial agents. Many of the bioactive substances found in different spices have antimicrobial activity ${ }^{[4]}$. Steps must be taken to monitor this scenario, including use of antimicrobial plant extracts with physicochemical and biological properties ${ }^{[5]}$. Spices have been recognized for their value in food preservation and their medicinal value due to the presence of bioactive antimicrobial compounds $\mathrm{s}^{[6,7]}$.

Curcumin is a food coloring and flavoring agent that has been shown to exert antioxidant effects both in vitro and in animal studies. Curcumin is known as the active component of turmeric and has shown inhibitory activity against microorganisms ${ }^{[8]}$.

Garlic (Allium sativum) is a dietary spice belonging to the Amaryllidaceae family with therapeutic effectiveness attributed to its oil and water-soluble organosulfur compounds ${ }^{[9]}$. Thiosulfates are mainly responsible for the antibiotic activity of garlic, as evidenced by the fact that extracts of garlic free of thiosulfinates normally lose their antimicrobial capacity ${ }^{[10]}$. Garlic is also said to help reduce heart diseases, such as atherosclerosis, elevated blood pressure, and high cholesterol, and certain forms of cancer, including cancers of the stomach and colon ${ }^{[11]}$. The antimicrobial efficacy of turmeric and garlic extracts against many clinical bacterial isolates, namely Staphylococcus aureus, Escherichia coli, and Klebsiella pneumoniae, was mentioned in this section.

\section{Materials and Methods}

\section{Cleaning and Sterilization of Glassware}

All glassware used was washed thoroughly with detergent, rinsed with clean water, and sterilized in an oven at $160{ }^{\circ} \mathrm{C}$ for 1 hour.

\section{Sample Plant Materials}

Turmeric and garlic were purchased from Mangu market in Plateau state and transported inside a sterile polyethylene bag to the Microbiology Laboratory, Federal Polytechnic Bauchi Science Laboratory Technology Department.

\section{Ethical Clearance and Informed Consent}

The study involved the use of isolates; therefore, ethical clearance from the facility was not needed, and informed consent was not sought.

\section{Test Microorganisms}

The bacterial isolates used in the present research were collected from the Bauchi Teaching Hospital. Staphylococcus aureus, Escherichia coli, and Klebsiella pneumoniae were the bacteria used, and the isolates were confirmed by coagulase, catalase, and indole tests, accordingly. The isolates were further subcultured in peptone water and stored until analysis.

\section{Sample Preparation}

Fresh turmeric was peeled, washed, coarsely minced, and sliced. Garlic was peeled and air dried at ambient temperature for two weeks, then coarsely minced and sun dried for two additional weeks. Using a sterile pestle and mortar from the department's microbiology laboratory, the dried plants were ground into a powder. 


\section{Preparation of Ethanol Extract of Turmeric and Garlic}

Samples $(40 \mathrm{~g}$ ) of each fine spice powder of turmeric and garlic were measured on an electronic balance. The weighed spices were then dispensed into two beakers containing $200 \mathrm{ml}$ of $95 \%$ ethanol each. The spices were soaked for $72 \mathrm{~h}$, after which the solution was carefully filtered with a muslin cloth into a sterilized $250 \mathrm{ml}$ conical flask, and the obtained filtrates were stored in a refrigerator at $4{ }^{\circ} \mathrm{C}$ until required.

\section{Preparation of Water Extract of Turmeric and Garlic}

The weighed spices were dispensed into two sterilized beakers, each consisting of $200 \mathrm{ml}$ of distilled water, then soaked for $72 \mathrm{~h}$, after which the solution was carefully filtered into two sterilized $250 \mathrm{ml}$ conical flasks with a muslin cloth, and the filtrate was kept in a refrigerator at $4{ }^{\circ} \mathrm{C}$ until use ${ }^{[12]}$.

\section{Media Preparation}

Nutrient broth and nutrient agar were prepared according to the manufacturer's instructions.

\section{Phytochemical Screening}

The concentrated extracts were subjected to chemical tests for the detection of various phytochemical constituents which include Alkaloid, Saponin, Phlobatanin, Tannin, Steroid, Terpenoid, Flavonoid, Anthraquinone using the methods described in $^{[13,14]}$.

\section{Alkaloid Screening}

Samples of spice extracts ( $0.5 \mathrm{~g}$ each) were mixed for 2 minutes in a steam bath with $5 \mathrm{ml}$ of 1\% aqueous hydrochloric acid $(\mathrm{HCl})$. The blends were purified, and a few drops of Dragendoff's reagent were applied. The samples were observed for color changes.

\section{Saponin Screening}

The saponin continuous frothing test was used. Samples (1 g) of each of the spice extracts were combined with purified water $(30 \mathrm{ml})$. The mixture was shaken and cooked vigorously in a steam bath. Afterwards, the sample was observed for froth formation.

\section{Phlobatanin Screening}

Each of the spice extracts $(0.2 \mathrm{~g})$ was dissolved in $10 \mathrm{ml}$ of purified water and filtered. The supernatants were boiled with a $2 \%$ solution of $\mathrm{HCl}$ and observed for red precipitate deposition, suggesting the presence of phlorotannins.

\section{Tannin Screening}

Each spice extract $(0.5 \mathrm{~g})$ was dissolved in $5 \mathrm{ml}$ of distilled water, carefully boiled, and cooled down. In the test tubes, $1 \mathrm{ml}$ of each solution was dispensed, and three drops of $0.1 \%$ ferric chloride solution were applied. The preparation was observed for brownish green or blue-black coloration ${ }^{[15]}$.

\section{Steroid Screening}

Samples $(0.5 \mathrm{~g})$ of each spice extract were diluted with acetic anhydride $(2 \mathrm{ml})$. The filtrate was combined with sulfuric acid (2 $\mathrm{ml})$. The presence of steroids suggests a color shift from violet to blue or green.

\section{Terpenoid Screening}

Five milliliters of each spice extract was combined with $2 \mathrm{ml}$ of chloroform, and condensed sulfuric acid $\left(\mathrm{H}_{2} \mathrm{SO}_{4}\right)$ was carefully applied to form a layer. Each solution was then observed for reddish-brown coloration to evidence the existence of terpenoids.

\section{Flavonoid Screening}

A portion of the aqueous filtrate of each spice extract was added to the diluted ammonia solution $(5 \mathrm{ml})$, followed by the incorporation of condensed sulfuric acid. The existence of flavonoids is shown by yellow coloration that disappears on standing.

\section{Anthraquinone Screening}

The Borntrager test for the identification of anthraquinones was used. The spice extract $(0.5 \mathrm{~g})$ was shaken with $10 \mathrm{ml}$ of benzene. The mixture was filtered, and the filtrate was applied to $5 \mathrm{ml}$ of $10 \%$ ammonia solution and then shaken. In the ammonia layer of the preparation, the appearance of a pink-red or violet dye suggests the presence of free anthraquinones.

\section{Antibacterial Activity by the Process of Agar Well Diffusion}

Standard suspensions of the test organisms, i.e., Staphylococcus aureus, Escherichia coli, and Klebsiella pneumoniae, were poured or inoculated into Petri dishes containing Nutrient Agar, and the plate was allowed to solidify. Five wells were perforated with an 8-mm-diameter sterile cork borer and numbered with separate extract concentrations of 100,75, 50, and $25 \mathrm{mg} /$ $\mathrm{ml}$, an ofloxacin positive control with $10 \mathrm{mg} / \mathrm{ml}$ absorption for Staphylococcus aureus, and a nalidixic acid control with $30 \mathrm{mg} / \mathrm{ml}$ absorption for both Escherichia coli and Klebsiella pneumoniae. Using a sterile pipette, along with the positive control, $0.5 \mathrm{mg} / \mathrm{ml}$ of turmeric and garlic extracts were added to the well. The plates were then incubated at $37^{\circ} \mathrm{C}$ for $24 \mathrm{~h}^{[16]}$. Using a calibrated ruler, the mean diameters of the inhibition zones were determined in millimeters, and the effects were reported.

\section{Statistical Analysis}

The results of the study are presented using descriptive statistics (frequency and percentage) and displayed in tables. 


\section{Results and Discussion}

The phytochemicals present in ethanol and aqueous extracts of turmeric and garlic are presented in Table 1. From the table, steroids, flavonoids, terpenoids, and alkaloids were present in both extracts of turmeric and garlic, whereas anthraquinone was only present in turmeric and absent in garlic. Saponins and tannins were present in the garlic extract.

Table 2 presents the antimicrobial activity of turmeric ethanol extract against the clinical bacterial isolates examined, showing an inhibition zone of $13 \mathrm{~mm}$ at a concentration of $100 \mathrm{mg} / \mathrm{ml}$ against Staphylococcus aureus and $7 \mathrm{~mm}$ at a concentration of $100 \mathrm{mg} / \mathrm{ml}$ against Klebsiella pneumoniae, whereas Escherichia coli was immune to the extract.

The antimicrobial activity of the aqueous turmeric extract showed an $11 \mathrm{~mm}$ inhibition zone at the $100 \mathrm{mg} / \mathrm{ml}$ concentration against Staphylococcus aureus and a $7 \mathrm{~mm}$ inhibition zone at the $100 \mathrm{mg} / \mathrm{ml}$ concentration against Klebsiella pneumoniae, whereas Escherichia coli was resistant to the extracts.

Table 3 presents the findings of the antimicrobial activity of ethanol and aqueous garlic extracts against the tested clinical bacterial isolates. From the table, the ethanol extract revealed

\begin{tabular}{|c|c|c|c|c|}
\hline Phytochemical constituent & TEE & TAE & GEE & GAE \\
\hline Steroids & + & + & + & + \\
\hline Flavonoid & + & + & + & + \\
\hline Saponin & - & - & + & + \\
\hline Tannin & - & - & + & + \\
\hline Terpenoids & + & + & + & + \\
\hline Alkaloids & + & + & + & + \\
\hline
\end{tabular}

TEE: Turmeric ethanol extract, TAE: Turmeric aqueous extract, GEE: Garlic ethanol extract, GAE: Garlic aqueous extract

"+" = Present,"-" = Absent

Table 2. Antimicrobial activity of turmeric aqueous/ethanol extract on Staphylococcus aureus, Escherichia coli, and Klebsiella pneumoniae

\begin{tabular}{|c|c|c|c|c|c|c|}
\hline \multirow[t]{3}{*}{ Absorptions of extract $(\mathrm{mg} / \mathrm{ml})$} & \multicolumn{6}{|c|}{ Diameter of inhibition (mm) } \\
\hline & \multicolumn{2}{|c|}{ Staphylococcus aureus } & \multicolumn{2}{|c|}{ Escherichia coli } & \multicolumn{2}{|c|}{ Klebsiella pneumoniae } \\
\hline & Aqueous & Ethanol & Aqueous & Ethanol & Aqueous & Ethanol \\
\hline 75 & 7 & 7.5 & 0 & 0 & 0 & 0 \\
\hline 50 & 0 & 0 & 0 & 0 & 0 & 0 \\
\hline C & 20 & 20 & 15 & 15 & 19 & 19 \\
\hline
\end{tabular}

C: Control

Table 3. Antimicrobial activity of garlic aqueous/ethanol extract on Staphylococcus aureus, Escherichia coli, and Klebsiella pneumoniae

\begin{tabular}{|c|c|c|c|c|c|c|}
\hline \multirow[t]{3}{*}{ Absorptions of extract $(\mathrm{mg} / \mathrm{ml})$} & \multicolumn{6}{|c|}{ Diameter of inhibition (mm) } \\
\hline & \multicolumn{2}{|c|}{ Staphylococcus aureus } & \multicolumn{2}{|c|}{ Escherichia coli } & \multicolumn{2}{|c|}{ Klebsiella pneumoniae } \\
\hline & Aqueous & Ethanol & Aqueous & Ethanol & Aqueous & Ethanol \\
\hline 75 & 8 & 10 & 6 & 8 & 6 & 6 \\
\hline 50 & 0 & 0 & 0 & 6 & 0 & 0 \\
\hline
\end{tabular}


an inhibition zone of $12 \mathrm{~mm}$ at the $100 \mathrm{mg} / \mathrm{ml}$ concentration against Staphylococcus aureus, an inhibition zone of $10 \mathrm{~mm}$ at the $100 \mathrm{mg} / \mathrm{ml}$ concentration against Escherichia coli, and an inhibition zone of $7 \mathrm{~mm}$ at the $100 \mathrm{mg} / \mathrm{ml}$ concentration against Klebsiella pneumoniae. The same garlic aqueous extract was inhibitory to the bacteria examined.

The synergistic effect of ethanol and aqueous extracts of turmeric and garlic had a major effect on the bacterial isolates examined (Table 4).

The findings of the phytochemical study carried out on turmeric and garlic extracts are shown in Table 1. It can be seen from this table that steroids, flavonoids, terpenoids, and alkaloids were present in both spice extracts, except for anthraquinone, which was present in turmeric extract and absent in garlic, so that saponins and tannins were also present in garlic extract and absent in turmeric extract. The antimicrobial activity of these compounds has been confirmed, and their presence in turmeric and garlic extracts may explain the activity documented against these test organisms. Tannin has been reported to interfere with the synthesis of microbial cell proteins and is essential for the treatment of tissues that are ulcerated or inflamed and for the treatment of intestinal disorders ${ }^{[17]}$. Alkaloid has also been reported to be a pain reliever and saponin has an inflammation control effect ${ }^{[18]}$. Flavonoid is also important against inflammation and microorganisms. This is in line with the work of ${ }^{[19]}$, who reported that herbal medicinal plants possess inherent ingredients (secondary metabolites) that make them effective as treatments for various ailments.

The antimicrobial activity of turmeric extracts was assessed by the presence or absence of an inhibition zone around Staphylococcus aureus, Escherichia coli, and Klebsiella pneumoniae (Table 2), and various concentrations of the extract showed differently sized zones of inhibition on the clinical isolate. Ethanolic extract of turmeric showed the largest zone of inhibition of $13 \mathrm{~mm}$ at an absorption of $100 \mathrm{mg} / \mathrm{ml}$, whereas the largest zone of inhibition recorded for the aqueous extract of turmeric was $11 \mathrm{~mm}$ at a concentration of $100 \mathrm{mg} /$ $\mathrm{ml}$, and the various activities decrease with decreasing extract concentration. No inhibition zone was observed for Escherichia coli. The bacterium was immune to both ethanol and turmeric aqueous extract. Resistance may be associated with either the lipid bilayer of the outer membrane of the bacterium preventing the extracts from entering or antioxidants, molecules that prevent the oxidation of other molecules. Oxidation is a chemical reaction that can create free radicals that can kill cells by leading to chain reactions. The bacterium may also have been able to generate enzymes that alter the extracts chemically, thereby interfering with the extract's activity, rendering it ineffective. The bacterium can also be prevented from binding to the extract by small structural changes in the target bacterium. A change in the ribosomal RNA, the macrolide target, can also prevent the extract from interfering with the function of the ribosome. The porin protein in the Gram-negative bacterias outer membrane selectively allows small hydrophobic molecules to enter a cell. Changes in these proteins can therefore prevent the entry of certain drugs into the cell and thus influence the effect. The mechanism used by the bacteria to transfer harmful substances out of a cell is often called an efflux pump. In the increased removal of drugs, when a cell produces more pumps, they will affect the extract range that can be pumped out, which may allow the organism to become immune to many drugs at the same time ${ }^{[20]}$. At a $100 \mathrm{mg} / \mathrm{ml}$ concentration, an inhibition zone of $7 \mathrm{~mm}$ was reported for both ethanolic and aqueous extracts of turmeric against Klebsiella pneumoniae, which decreased as the extract concentration decreased.

Garlic extracts showed different inhibition zones on the tested species at different absorption levels in Table 3. Garlic spice ethanol extract displayed an inhibition zone of $12 \mathrm{~mm}$ at 100 $\mathrm{mg} / \mathrm{ml}$ absorption for Staphylococcus aureus and an inhibition zone of $10 \mathrm{~mm}$ at $100 \mathrm{mg} / \mathrm{ml}$ absorption for Escherichia coli, and an inhibition zone of $7 \mathrm{~mm}$ at $100 \mathrm{mg} / \mathrm{ml}$ absorption for Klebsiella pneumoniae. The aqueous extract of the same spice showed an inhibition zone of $10 \mathrm{~mm}$ at $100 \mathrm{mg} / \mathrm{ml}$ absorption for Staphylococcus aureus, an inhibition zone of $9 \mathrm{~mm}$ at the $100 \mathrm{mg} / \mathrm{ml}$ concentration for Escherichia coli, and an inhibition zone of $8 \mathrm{~mm}$ at the $100 \mathrm{mg} / \mathrm{ml}$ concentration.

The combined effects of turmeric and garlic extracts on the test organisms are presented in Table 4 and were found to be the most effective at inhibiting microbial growth. In contrast to Gram-negative bacteria, Gram-positive bacteria were more likely to be inhibited by the extract; Gram-negative bacteria are usually expected to be more resistant to antibiotics than Grampositive bacteria ${ }^{[21]}$, the results were as expected.

The differential antimicrobial activity of extracts against various microbes may be attributed to the existence of various phytochemical compounds ${ }^{[22]}$. antimicrobial activity of alcoholic

Table 4. Synergistic effect of ethanol and aqueous extracts of turmeric and garlic on Staphylococcus aureus, Escherichia coli, and Klebsiella pneumoniae

\begin{tabular}{|c|c|c|c|c|}
\hline \multirow[b]{2}{*}{ Bacterial isolate } & \multicolumn{4}{|c|}{ Diameter of inhibition $(\mathrm{mm})$ against microorganisms } \\
\hline & Staphylococcus aureus & Escherichia coli & Klebsiella pneumoniae & Extraction solvents \\
\hline Turmeric/garlic & 13 & 5 & 7 & Ethanol \\
\hline
\end{tabular}


turmeric extract against different microorganisms was examined to have Important growth inhibition against Agrobacterium tumefaciens, Bacillus subtilus, Enterobacter aerogenes, and Escherichia coli, but no growth of any fungi against ${ }^{[23]}$. Excellent to moderate inhibitory effects of garlic extract spices on bacterial strains of Salmonella typhi, Escherichia coli, and Staphylococcus aureus at similar concentrations have been studied ${ }^{[24]}$. The antibacterial activity of garlic is a documented consequence of the action of allicin or dialkyl thiosulphoric acid or diallyl disulfate ${ }^{[25]}$. The antibacterial properties of garlic juice are postulated to be due to the inhibition of succinyl dehydrogenase through thiol group inactivation. The outcome of the present study also agrees with the finding that turmeric extracts do not inhibit the development of Escherichia coli. In a study by Skrinjar and Nemet ${ }^{[25]}$, the antimicrobial activity of the essential oils of garlic and turmeric was tested against the most common foodborne bacteria and fungi, including Listeria spp., Staphylococcus spp., Salmonella spp., Escherichia spp., Cladosporium spp., and garlic and turmeric were stated to have very strong and medium inhibitory effects, respectively. As garlic had the highest antimicrobial activity, the outcome of the current study agrees with these observations, and turmeric demonstrated a medium inhibitory effect.

\section{Study Limitations}

The research is limited to the use of turmeric and garlic extracts, and the test species are confined to Staphylococcus aureus, Escherichia coli, and Klebsiella pneumoniae.

\section{Conclusion}

Based on findings from this study of the antimicrobial activity of turmeric and garlic spice extracts, it can be concluded that these spices can be used as effective antimicrobial agents against Gram-positive and Gram-negative bacteria, individually and in combination. Extract combinations can have inhibitory additive or synergistic effects, making them more effective as antimicrobial agents. Although spices have been historically used as food preservatives and antiseptics, their antimicrobial properties need to be identified by standardizing their concentrations in combined extracts to achieve an optimal inhibitory impact.

\section{Ethics}

Ethics Committee Approval and Informed Consent: The study involved the use of isolates; therefore, ethical clearance from the facility was not needed, and informed consent was not sought.

Peer-review: Externally peer-reviewed.

\section{Authorship Contributions}

Concept: N.M.W., A.A.A., S.K.B., Design: N.M.W., A.A.I., Data Collection or Processing: N.M.W., A.A.I., S.K.B., Analysis or Interpretation: N.M.W., A.A.A., Literature Search: N.M.W., A.A.I, A.U., Writing: N.M.W., A.A.A., A.U., D.T.J.

Conflict of Interest: No conflict of interest was declared by the authors.

Financial Disclosure: The authors declared that this study received no financial support.

\section{References}

1. Kumar A, Sharma P, Mahajan A, Begum Z. In Vitro Comparative Study of Antioxidant and Antibacterial Activity of Selected Dietary Plants. Nepal Journal of Biotechnology 2018;6:39-45.

2. Surh YJ. Anti-tumor promoting potential of selected spice ingredients with antioxidative and anti-inflammatory activities: a short review. Food Chem Toxicol. 2002;40:1091-7.

3. Nanasombat $S$, Presertsin V, Graisin K, Shain H, Thanabonipat B. Efficacy of new enzyme-linked immunosorbent Assay for Rapid Detection of salmonella in foods. Government Pharmaceutical Organisation Report, Bangkok, 2002;51:53-7.

4. Luis Â, Duarte A, Gominho J, Domingues F, Duarte AP. Chemical composition, antioxidant, antibacterial and anti-quorum sensing activities of Eucalyptus globulus and Eucalyptus radiata essential oils. Industrial Crops and Products. 2016;79:274-82.

5. Agaoglu S, Dostbil N, Alemdar S. Antimicrobial activity of spices used in the meat industry. Bull Vet Inst Pulaway. 2007;51:53-7.

6. Shelef LA. Antimicrobial Effects of Spices. J Jood Saf. 1984;6:29-44.

7. Papp LV, Lu J, Holmgren A, Khanna KK. From selenium to selenoproteins: synthesis, identity, and their role in human health. Antioxid Redox Signal. 2007;9:775-806

8. Niamsa N, Sittiwet C. Antibacterial Activity of Curcuma longa aqueous extract. Pharma J Toxicol. 2009;4:173-7.

9. Mukhtar S, Ghori I. Antibacterial activity of aqueous and ethanolic extracts of garlic, cinnamon and turmeric against Escherichia coli ATCC 25922 and Bacillus subtilis DSM 3256. Int J Appl Biol Pharm. 2012;3:131-6.

10. Hughes BG, Lawson LD. Antimicrobial effects of Allium sativum L.(garlic), Allium ampeloprasum L. (elephant garlic) and Allium cepa L.(onion), garlic compound and commercial garlic supplement products.Phytother Res. 1991;5:154-8.

11. Rajsekhar S, Kuldeep B, Chandaker A, Upmanyu N. Spices as antimicrobial agents: a review, Int Res J Pharm. 2013; 3:1-9.

12. Olayemi $A B$, Opaleye FI. Antibiotic resistance among coliform bacteria isolated from hospital and urban wastewaters. World J Microbiol Biotechnol. 1990;6:285-8. Trease GA, Evans MC (2005). Pharmacognosy. $12^{\text {th }}$ Edn New Delhi, India.

13. Harborne JB (2005). Phytochemical methods. A guide to modern techniques of plant analysis, New Delhi, Springer PVT Itd.

14. Trease GA, Evans MC (2005). Pharmacognosy. $12^{\text {th }}$ Edn New Delhi, India.

15. Olayemi $A B$, Opaleye Fl. Antibiotic resistance among coliform bacteria isolated from hospital and urban wastewaters. World J Microbiol Biotechnol. 1990;6:285-8. 
16. Igbinosa 00, Igbinosa EO, Aiyegoro OA. Antimicrobial activity and phytochemical screening of stem bark extracts of Jatropha curcas (Linn). Afr J Pharm Pharmacol. 2009;3:58-62.

17. Hussain S, Siddiqui SU, Khalid S, Jamal A, Qayyum A, Ahmad Z. Allelopathic potential of senna (Cassia angustifolia) on germination and seedling characters of some major cereal crops and their associated grassy weeds. Pak J Bot 2007;39:1145-53.

18. Shukla V, Mishra G, Dwivedi M. In vitro inhibition of tinea corpons from the various extract of Aloe vera and Azadirachta indica. Acta Scientific Microbiol. 2018;1:16-23.

19. Joe MM, Jayachitra J, Vijayapriya M. Antimicrobial activity of some common spices against certain human pathogens. J Med Plant Res. 2009;3:1134-6.

20. Zaika LL, Kissinger JC. Inhibitory and stimulatory effect of Oregano on lactobacillus plantarum and Pediococcus cerevisiae. J Food Sci. 1981;46:1205-10.
21. Britto A, Gracelin $D_{1}$. Benjamin $P_{1}$ Kumar JR. Antibacterial Potency and Synergistic Effect of a few South Indian Spices against Antibiotic-Resistant bacteria. Indian Journal of Natural products and Resources. 2012;3:557-62.

22. De Clercq E. Strategies in the design of antiviral drugs. Nat Rev Drug Discov. 2002;1:13-25.

23. Gull I, Saeed M, Shaukat H, Aslam SM, Samra ZQ, Athar AM. Inhibitory effect of Allium sativum and Zingiber officinale extracts on clinically important drug resistant pathogenic bacteria. Ann Clin Microbiol Antimicrob. 2012;11:8.

24. Avato $\mathrm{P}$, Tursil E, Vitali C, Miccolis V, Candido V. Allylsulfide constituents of garlic volatile oil as antimicrobial agents. Phytomedicine. 2000;7:239-43.

25. Skrinjar MM, Nemet NT. Antimicrobial effects of spices and herbs essential oils. Acta Period Technol. 2009;40:195-209. 